\title{
IMPACT OF HEAVY METALS POLLUTION ON HISTOPATHOLOGICAL ALTERATIONS IN KIDNEY AND LIVER OF NILE TILAPIA (OREOCHROMIS NILOTICUS) INHABITING EL-RAHAWY DRAIN
}

\author{
A.M . El-Hais ${ }^{1}$, Magdoleen M . A . El-Hosseiny ${ }^{2}$, Soad A. Mahmoud ${ }^{2}$, M.A . El-Kasheif ${ }^{2}$, \\ Sara S. Said ${ }^{2}$ and S.A. Abd-Allah ${ }^{3}$ \\ ${ }^{I}$ Department of Animal production, Faculty of Agriculture, Tanta University, Tanta. \\ ${ }^{2}$ National Institute of Oceanogeaphy and Fisheries, Cairo, Egypt. \\ ${ }^{3}$ Department of plant protection, Faculty of Agriculture, Tanta University, Tanta.
}

\section{SUMMARY}

\begin{abstract}
$\mathrm{T}$ his study was performed to evaluate agricultural and industrial wastes water with respect to the potentially some toxic metals on histopathological alterations in kidney and liver of Nile tilapia (Oreochromis niloticus) from El-Rahawy drain at different seasons. Samples of Nile tilapia (Oreochromis niloticus) were collected seasonally (12 fish / season) from each site. Fish total length and total weight were from 13.5 to $26.1 \mathrm{~cm}$ and from 50 to $315 \mathrm{~g}$, respectively The present results indicated that, the heavy metals due to pollution, increased in tissue of fish caught from the drain. The distribution of heavy metals (Iron, Manganese, zinc, lead and copper) concentrations in water were estimated during four successive seasons were found to be , Fe $(0.680,0.626,0.380,0.395 \mathrm{mg} / \mathrm{L})$, Mn $(0.214,0.173,0.112$, $0.214 \mathrm{mg} / \mathrm{L}), \mathrm{Zn}(0.138,0.120,0.107,0.108), \mathrm{Pb}(0.041,0.054,0.050,0.049 \mathrm{mg} / \mathrm{L})$ and $\mathrm{Cu}(0.006$ $, 0.010,0.009,0.007 \mathrm{mg} / \mathrm{L})$, respectively. It was found that, the heavy metals were accumulated in the studied fish muscle by various levels. The concen tration of the tested metals in fish muscle of (edible parts) followed a sequence of $\mathrm{Fe}>\mathrm{Zn}>\mathrm{Mn}>\mathrm{Cu}>\mathrm{Pb}$. Also, the results showed that, elevation in studied heavy metals concentrations caused histological alterations in collected fish. These alterations including: hemorhage, degeneration, hemosiderin and oedema in hematopiotic tissue, also observed necrosis in renal tubule and glomerulus of the kidney while showed marked histopathological changes in the liver of studied fish revealed hemolysis and hemosiderin in blood vessel. It was concluded that, agricultural, industrial and domestic wastes histopathological alterations were observed in the kidney and liver of Nile tilapia (Oreochromis niloticus) collected from El-Rahawy drain.
\end{abstract}

Keywords: Pollution, heavy metals, El-Rahawy drain, Nile tilapia, histopathology, kidney, liver.

\section{INTRODUTION}

Aquatic ecosystems are major recipients of pollutants, which over time, can have serious consequences for the biota that might not become apparent until changes occur at the population or ecosystem level, a point at which it may be too late to take effective countermeasures ( Khallaf et al,. 2010) . In Egypt, the problems of the drainage canals have extremely increased in the past years (Authman et al., 2013). Where disposing of partially treated or untreated domestic and industrial wastewater into agricultural drains deteriorates their water quality [El-Sheikh et al., 2010].

El-Rahawy drains is one of the main drains; it starts as El-Rahawy pump station on Mansouria Rayah lies at $30 \mathrm{~km}$, North to Cairo at El-Kanater El-khayria in area, Egypt. El-Rahwy drain lies between latitudes $30010, \mathrm{~N}$ to $30012^{\prime} \mathrm{N}$ and longitudes $3102^{\prime} \mathrm{E}$ to 3103 , E. It is about $12.41 \mathrm{~km}^{2}$ and passes through El-Rahawy village and many villages distributed along it receiving agricultural and domestic wastes without purification in addition to sewage of El-Giza governorate and discharge these wastes directly without treatment into Rosetta branch of the River Nile [El Bouraie et al. 2010].

The drain is surrounded by high density of population area and wide agricultural lands. The surface level of the drain is $12.37 \mathrm{~m}$ above sea level. This drain receives waste water from El-Moheet drain that passes by a deep under El-Nassery sub-brunch of the River Nile to open into a concrete reservoir of about $20 \mathrm{~m}$ high at El-Rahawy drain. From this reservoir, the drainage wastewater runs to about $4 \mathrm{~km}$ through ElRahawy village and opens into Rosetta branch. The drain discharges about $2.800000 \mathrm{~m}^{3} / \mathrm{day}$ of which about $1.90000 \mathrm{~m} 3 /$ day sewage effluents. The surface level of the drainage wastewater in the reservoir is about $13 \mathrm{~m}$ higher than the water in Rosetta branch. Gaber et al. (2013) showed that, the heavy metals 
concentrations ( $\mathrm{Cu}, \mathrm{Fe}, \mathrm{Pb}, \mathrm{Cd}, \mathrm{Mn}$ and $\mathrm{Zn}$ ) in water are higher in El-Rahawy drain than in River Nile and this due to sewage and other pollutants discharge, also showed significant changes and histological abnormalities of stomach, intestine and gonads of African catfish clarias gariepinus . The need of detect and assess the impact of pollutants, particularly at low, sub lethal concentrations, on environmental quality had led to development of a range of biological responses measured in number of different species [Fen, 2004 and Linde -Arias et al., 2008]. Fish are generally considered to be the most feasible organisms for pollution monitoring in aquatic systems. Fish can be found virtually everyhere in the aquatic environment and they play a major ecological role in aquatic food-webs because of their function as carrier of energy from lower to higher trophic levels [Linde -Arias et al., 2008 and Van der Oost et al, 2003].

Fish live in their environment, are extremely dependent upon it and are affected by changes in it. Thus fish could be used as a "warning system" to indicate the presence of pollutants in natural water [Nussey et al, 1995]. Prior to death or overt sickness, fish may respond to stress by changing molecular, physiological, histological or behavioural responses.

Midhat et al. ( 2013 ) observed that, the heavy metals concentrations in water from El-Rahawy drain region were higher than those obtained from River Nile and the Nile catfish Clarias gariepinus inhabiting in the drain suffer from many histopathological changes in the kidney and spleen including degeneration, necrosis, haemorrhage, activation of melanomacrophage centers, hyperplasia and hemosiderosis .

The aim of this study to estimate industrial waste water effect on histopathological alterations in kidney and liver of Nile tilapia (Oreochromis niloticus) from El-Rahawy drain.

\section{MATERIALS AND METHODS}

The present study was extended from winter to autumn 2016 during four successive seasons in El-Rahawy drain at El-Rahawy Village, El-Giza governorate. Samples were collected from ElRahawy drain, Fig.(1) to represent the drain ecosystem.

Sampling, preservation and experimental procedure of the water samples were carried out according to the standard methods for examination of wastewater [APHA, 1998]. Heavy metals (iron, manganese, zinc, lead and copper ) in water samples were determined using atomic absorption spectrometry ( Perkin - Elmer 3110, USA) with graphite atomizer HGA - 600, after using the digestion technique by nitric acid [APHA, 1998].

\section{Fish Samples Collection and Analysis:}

Samples of Nile tilapia (Oreochromis niloticus) were collected seasonally (12 fish / season) from each site of about 13.5 to $26.1 \mathrm{~cm}$ and from 50 to $315 \mathrm{~g}$, respectively. The fishes were transposed alive back after catching to the laboratory for subsequent analysis. In the laboratory, for each fish, the total length and total weight were recorded.

\section{Heavy metals in water}

Samples of water of 1 liter were collected from the selected station in poly ethylene bottles. The bottles were previously rinsed several times with river water before collection. The entire sample was acidified using $5 \mathrm{ml}$ concentrated nitric acid at collection. In the laboratory, $20 \mathrm{ml}$ of nitric acid was added to $500 \mathrm{ml}$ of water sample in a beaker and boiled on a hot plate till the lowest volume, nearly 15 $20 \mathrm{ml}$ before precipitation occurs, until complete digestion. The remaining volume was completed to 100 $\mathrm{ml}$ with deionized distilled water. A portion of this solution was used for the determination of heavy metals. The metals concentration ( $\mathrm{Fe}, \mathrm{Cu}, \mathrm{Mn}, \mathrm{Zn}$ and $\mathrm{Cd}$ ) were determined using atomic absorption model (Perkin Elmer 3110 USA) with graphite atomizer HGA-600, according to the method described by APHA (1998). The results were expressed in $\mu \mathrm{gl}-1$.

\section{Heavy metals in fish organ}

Specimens of the major organ muscles, spleen, gills, liver and kidney were collected from 5 fishes and were transferred to beaker in a drying oven thermostatically regulated at $105{ }^{\circ} \mathrm{C}$ overnight. One gm dry weights of organs were digested according to the method described by Goldberg et al. (1963) in which concentrated $\mathrm{HNO}_{3}$ and $\mathrm{HClO}_{4}$ with ratio of $5 \mathrm{ml}+5 \mathrm{ml}$ were used in Teflon beakers on hot plate at 50 ${ }^{0} \mathrm{C}$ for about 5 hours till complete decomposition of organic matter. The digested solution were cooled to 
room temperature, filtered and diluted to a final volume of $25 \mathrm{ml}$ using deionized water. The concentration of $\mathrm{Fe}, \mathrm{Mn}, \mathrm{Cu}, \mathrm{Zn}$ and $\mathrm{Cd}$ were determined using Hitachi model 170 - 30 with graphite atomizer (G.A.Z) atomic absorption spectrophotometer. The results were expressed in $\mu \mathrm{g} / \mathrm{g}$ dry weight.

\section{Histological studies}

Immediately after dissection of the fish muscles, liver, kidney, spleen and gills were fixed in $10 \%$ formalin at $4{ }^{0} \mathrm{C}$. The fixed organs were washed in running water (for $6-12$ hours), followed by dehydration through an ascending series of ethyl alcohol, (70\%, 80\%, $90 \%$ and two changes of $100 \%)$ and placed in two changes of xylene (1/4 - 3/4 hour for each change) before finally embedding in paraplast wax (m.p. $56-58{ }^{\circ} \mathrm{C}$ ). Transverse sections were cut at the thickness of $5 \mu \mathrm{m}$, using (Euromex Holand Microtone). Sections from at least 3 fishes for each organ were mounted on clean slides, staining was carried out according to (Bernet et al; 1999, hematoxylin and eosin method). Then the slides were cleaned and examined histopathologically by light microscope.

\section{Statistical Analysis:}

The basic statics, means and standard deviation of the measured parameters were estimated. Pearson's correlation coefficients matrixes among the different parameters were computed as well. All statistical analyses were done, using the computer program of SPSS Inc . (Version 17.0 for Windows) at the 0.05 level of significance (SPSS, 2002).

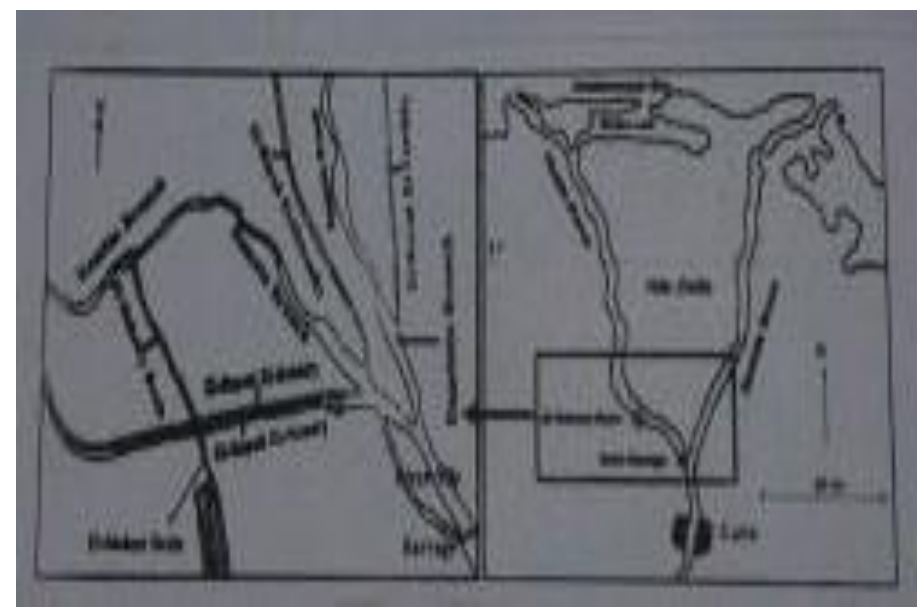

Fig. (1) : The study area at El-Rahawy drain, El-Rahawy village.

\section{RESULTS AND DISCUSSION}

Heavy metals in water reported (table 1) indicated that the values of the detected heavy metals in ElRahawy drain showed that, Fe to be the most abundant element in water whereas the $\mathrm{Cu}$ got the least concentration.

The present study was undertaken to determine the accumulation of Iron, Manganese, Zinc, Lead and Copper in muscles of Nile tilapia inhabiting the drain (Table 1). The relationship between the concentration of trace metals in water and their accumulation in O. niloticus muscles was clear in the present study. It can be inferred that fish accumulates trace metals in their muscles in higher quantities of Iron and Zinc than those found in ambient water during the four seasons. On the other hand, the concentration of studied trace elements were detected in fish muscles descending $\mathrm{Cu}<\mathrm{Pb}<\mathrm{Mn}$ while recorded between $(0.006-0.010),(0.041-0.054)$ and $(0.112-0.214) \mathrm{Mg} / \mathrm{L}$, respectively at ElRahawy drain.

The histopathological changes found in the kidney of $O$. niloticus fish collected from El-Rahawy drain, inclucle(F.2) (A) hemorrhage, degeneration in hematopoietic tissue and necrosis in renal tubule and glomerulus. Kidney showed degeneration, necrosis and hemosidrin in hematopoietic tissue (B). Necrosis in renal tubule and glomerulus, degeneration and necrosis in hematopoietic tissue (C). The hemorrhage and hemosidrin in hematopoietic tissue was appeared and oedema, necrosis, degeneration in renal tubule (D). There were numerous haemorrhage in hematopiotic tissue and edema, necrosis in 
renal tubule (E). There are edema and necrosis in glomerulus, renal tubule, glomerulus and hematopoietic tissue ( F ) .

Table (1): The water concentrations and muscles of heavy metals in the experimental area at different seasons of the year.

\begin{tabular}{|c|c|c|c|c|c|c|}
\hline & \multirow[t]{2}{*}{ Seasons } & \multicolumn{4}{|c|}{ Heavy metals concentrations (water) } & \multirow[b]{2}{*}{$\begin{array}{c}\text { Copper } \\
(\mathrm{Cu})\end{array}$} \\
\hline & & Iron $(\mathrm{Fe})$ & $\begin{array}{c}\text { Manganese } \\
(\mathrm{Mn})\end{array}$ & Zinc $(\mathrm{Zn})$ & Lead (pb) & \\
\hline & Winter & $\begin{array}{c}0.680 \\
\pm 0.124\end{array}$ & $\begin{array}{c}0.214 \\
\pm 0.054\end{array}$ & $\begin{array}{c}0.138 \\
\pm 0.020\end{array}$ & $\begin{array}{c}0.041 \\
\pm 0.003\end{array}$ & $\begin{array}{c}0.006 \\
\pm 0.001\end{array}$ \\
\hline & spring & $\begin{array}{c}0.626 \\
\pm 0.113\end{array}$ & $\begin{array}{c}0.173 \\
\pm 0.026\end{array}$ & $\begin{array}{c}0.120 \\
\pm 0.018\end{array}$ & $\begin{array}{c}0.054 \\
\pm 0.006\end{array}$ & $\begin{array}{r}0.010 \\
\pm 0.002\end{array}$ \\
\hline & Summer & 0.380 & 0.112 & 0.107 & $\begin{array}{c}0.050 \\
\pm 0.004\end{array}$ & $\begin{array}{c}0.009 \\
\pm 0.002\end{array}$ \\
\hline & autumn & $\begin{array}{c}0.395 \\
\pm 0.120\end{array}$ & $\begin{array}{c}0.214 \\
\pm 0.102\end{array}$ & $\begin{array}{c}0.108 \\
\pm 0.060\end{array}$ & $\begin{array}{c}0.049 \\
\pm 0.004\end{array}$ & $\begin{array}{c}0.007 \\
\pm 0.001\end{array}$ \\
\hline \multirow{2}{*}{$\begin{array}{l}\text { Egyptian Law } \\
\text { No. [16] }\end{array}$} & \multicolumn{6}{|c|}{ Permissible Limits (Mg /L) } \\
\hline & $(\mathrm{Mg} / \mathrm{L})$ & 1000 & 500 & 1000 & 50 & 1000 \\
\hline \multirow{6}{*}{ U.S. EPA [ 17] } & & 1000 & NA & 120 & 2.5 & 9.0 \\
\hline & Seasons & Heavy & tals concent & tions (Mus & & \\
\hline & Winter & $\begin{array}{c}2.073 \\
\pm 0.272\end{array}$ & $\begin{array}{c}0.086 \\
\pm 0.020\end{array}$ & $\begin{array}{c}0.377 \\
\pm 0.108\end{array}$ & $\begin{array}{c}0.015 \\
\pm 0.006\end{array}$ & $\begin{array}{c}0.044 \\
\pm 0.020\end{array}$ \\
\hline & spring & $\begin{array}{c}1.094 \\
\pm 0.180\end{array}$ & $\begin{array}{c}0.091 \\
\pm 0.016\end{array}$ & $\begin{array}{c}0.332 \\
\pm 0.142\end{array}$ & $\begin{array}{c}0.005 \\
\pm 0.001\end{array}$ & $\begin{array}{c}0.051 \\
\pm 0.012\end{array}$ \\
\hline & Summer & $\begin{array}{c}1.765 \\
\pm 0.164\end{array}$ & $\begin{array}{c}0.115 \\
\pm 0.060\end{array}$ & $\begin{array}{c}0.381 \\
\pm 0.060\end{array}$ & $\begin{array}{c}0.020 \\
\pm 0.004\end{array}$ & $\begin{array}{c}0.250 \\
\pm 0.073\end{array}$ \\
\hline & autumn & $\begin{array}{c}1.557 \\
\pm 0.123\end{array}$ & $\begin{array}{c}0.088 \\
\pm 0.001\end{array}$ & $\begin{array}{c}0.316 \\
\pm 0.130\end{array}$ & $\begin{array}{c}0.146 \\
\pm 0.032\end{array}$ & $\begin{array}{c}0.067 \\
\pm 0.018\end{array}$ \\
\hline
\end{tabular}

Anthropogenic sources such as agriculture run-off industrial and sewage have oriented both localized and regional pollution problems in nearly over country around the world (El Bouraie et al., 2011). In some oases the pollution has been extensive enough to lead to environmental disasters and ecosystem shutdown (Lasheen et al., 2012).

Heavy metals may enter an aquatic ecosystem from different natural and anthropogenic sources, including industrial or domestic sewage, storm runoff, leaching from landfills, shipping and harbor activities and atmospheric deposits(30.

Present results showed that, most of the heavy metal concentrations in surface water of ElRahawy drain and River Nile water are found within the permissible limka of both the Egyption governmental law No. 48 [Abeyede, 1993] and U.S.EPA [Abdel-Baky, 2001]. These results are in agreement with El-Bourale et al.(1993) who studied heavy metals in five drain outfalls and found that the level of metals is within the permissible limits of Egyptian law 48/ 1982. Also, Lasheen et al. [2012] stated that the average concentrations of heavy metals in El-Moheet drain: which discharge in El-Rahawy drain within the permissible range according to the Egyptian law 48/ 1982

The employment of histopathological biomarkers to determine the effects of environmental contamination has been perceived as a highly relevant methodology since they reflect the true health state of the organism Gaber et al. (2013). 
Similarly, histopathological investigations have long been recognized to be reliable biomarkers of stress in fish [Midhat et al., 2013 and Adeogun, 2012].

Histopathological analysis has already been tested and fioposed as an efficient and sensitive tool to the monitoring of fish health and environmental pollution in natural water bodies [Rajeshkumar. and Munuswamy, 2011].

Fish are notorious for their ability to concentrate heavy metals in their tissues. The matals exist most probably as cationic form in water $(\mathrm{Fe}, \mathrm{Mn}, \mathrm{Zn}, \mathrm{pb}, \mathrm{Cu})$ and tend to form ionic complexes and accumulate in the internal organs of fish (Mears and Eister, 1977). The present results showed that, the concentrations of heavy metals in the studied muscles of the fish ranged between $1.094-2.073$, $0.086-0.115,0.316-0.381,0.005-0.146$ and $0.044-0.250$ for $\mathrm{Fe}, \mathrm{Mn}, \mathrm{Zn}, \mathrm{pb}$ and $\mathrm{Cu}$, respectively. It was found that Fe concentration recorded higher accumulation in the muscle than the water during the winter season. Higher Fe content in muscle of O.niloticus can be attributed to the large quantities of $\mathrm{Fe}$ in water, this agree with the findings of Ghazaly et al. (1992), Tariq et al. (1993), Bahnasawy (2001) and Mohamed and Gad (2005). Iron concentrations in the water and muscle of fish is more than the maximum permissible level for Fe $(5.0 \mathrm{mg} / \mathrm{g}$ ) cited by Abeyede (1993).

The present study indicated that manganese concentration in the water ranged between 0.112 and $0.214 \mathrm{mg} / \mathrm{L}$ at El-Rahawy drain. Also, Mn concentration in the muscle of Nile tilapia ranged between $(0.086-0.088)$ in winter and autumn, respectively and $(0.091-0.115)$ in spring and summer seasons. respectively. The present results agree with the findings of Gomaa et al (1995) and Khallaf et al (1998) . On the other hand, Mn concentrations in the studied organs of C.gariepinus were in the following order : muscle < liver < kidney < gills, which agree the results of Abdel-Baky (2001) .

Zinc is an essential element and a common pollutant as well. It is taken up by fish directly from water especially by mucus and gills (skidmore, 1964). The present study showed that $\mathrm{Zn}$ concentrations in water and muscle were ranged between $(0.107-0.138)$ and $(0.316-0.381) \mathrm{mg} / \mathrm{L}$ during four seasons. The present results indicated that, $\mathrm{Zn}$ concentrations higher in the muscle of fish than water of the drain. The present results are in agreement with those obtained by Shenouda et al. (1992), Gomaa et al. (1995), khallaf et al. (1998) and Mohamed and Gad (2005). Western Australian food and drink Regulations recommended a level of $40 \mathrm{mg} / \mathrm{kg} \mathrm{Zn}$ for human consumption (Marks et al. , 1980) . Accordingly, the concentrations of $\mathrm{Zn}$ in the muscles of the studied fish are still below the permissible level.

Lead is toxic even at low concentrations and has no known function in biochemical processes. The present data explain that $\mathrm{pb}$ concentrations in muscles of the fish ranged between 0.005 and $0.146 \mathrm{mg} / \mathrm{g}$ dry wt. While, the concentrations of $\mathrm{pb}$ exhibited in water of the drain during four seasons. The present results agree with the results of Barak and Mason (1990), Ghazaly et al. (1992), Gomaa et al. (1995), Khallaf et al. (1998) and Mohamed and Gad (2005) .

Copper is an essential element for all living organisms. It is among the most toxic metals . The present study showed that copper concentrations in muscle of the studied Nile tilapia fish ranged between 0.044 and $0.250 \mathrm{mg} / \mathrm{g}$ dry weight for O. niloticus while recorded concentration (0.006 - 0.010) $\mathrm{mg} / \mathrm{L}$ were found in the water of the drain . The present results agree with the results of khallaf et al. (1998), Abdel-Baky (2001) and Mohamed and Gad (2005) Also Benedetti et al . (1989), Gomaa et al . (1995) and El-Moselhy (1999) found that $\mathrm{Cu}$ exhibited its higher levels in the liver and the lowest values in the muscles. The concentrations of $\mathrm{Cu}$ in the muscles of the studied fish are still below the permissible level for cu $(30 \mathrm{mg} / \mathrm{kg}$ ) recommended by National Health and Medical Research Council (NHMRC) Marks et al. (1980) . Mohamed and Gad (2005) showed that, the levels of $\mathrm{Fe}, \mathrm{Zn}, \mathrm{Mn}, \mathrm{Pb}$, $\mathrm{Cu}, \mathrm{Cd}$ in the water of Abu Zaabal Lakes ranged between $3022-6.01-0.21-1.50-0.67-1.64-0.62$ $-1.67,0.13-0.20-$ and $0.03-0.06 \mathrm{mg} / \mathrm{L}$. respectively, also who found that , the concentrations of the tested metals in different organs of the studied fish were in the following order $\mathrm{Fe}>\mathrm{zn}>\mathrm{pb}>\mathrm{Mn}>$ $\mathrm{Cu}>\mathrm{Cd}$ concentrations in the fish muscles (edible parts ) except $\mathrm{cd}$ in the muscles of T.Zillii were within the maximum permissible limit .

The liver of Oreochromis niloticus collected from El-Rahawy drain showed histopathological features (F. 3) .

Degeneration in blood vessel wall, fatty degeneration, pycnotic and necrosis in hapatocytes(A). Hemorrhage, hemosidrin in blood vessele, Congestion in blood sinusoids and necrosis in hepatocytes(B). The present study showed several alterations in the liver included hemolysis, hemosidrin, degeneration in blood vessel wall and necrosis in hepatocytes (C). 
Also, appeared hymolysis, necrosis and degeneration in blood vessel wall and hepatocytes (D) and $(\mathrm{E})$. However, there were microscopic differences that characterize the liver showed congestion in blood sinusoid, pycnotic, necrosis and degeneration in hepatocytes $(F)$.

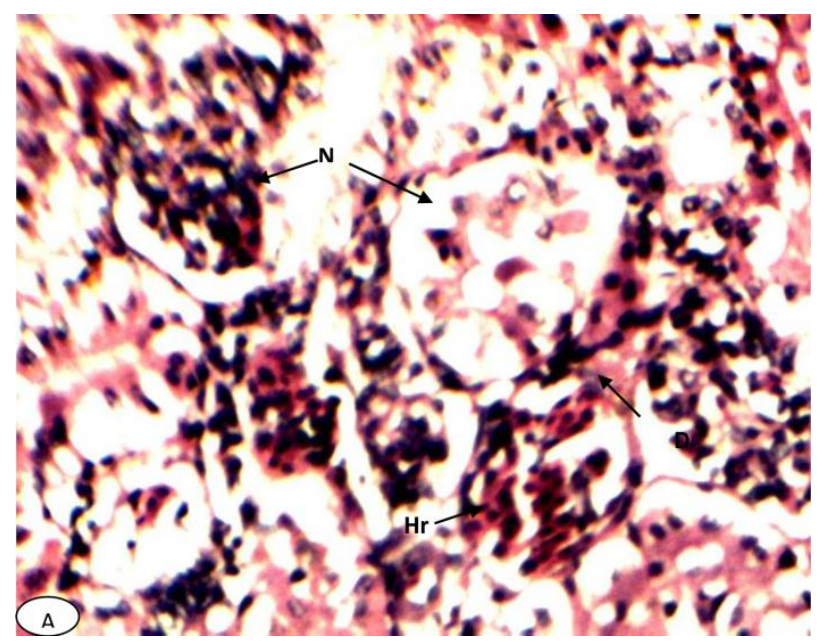

Fig (A): Kidney section of O. niloticus collected from ElRahawy drain showing: hemorrhage(Hr), and degeneration (D) in hematopoietic tissue, necrosis $(\mathrm{N})$ in renal tubule and glomerulus., HE. X 400

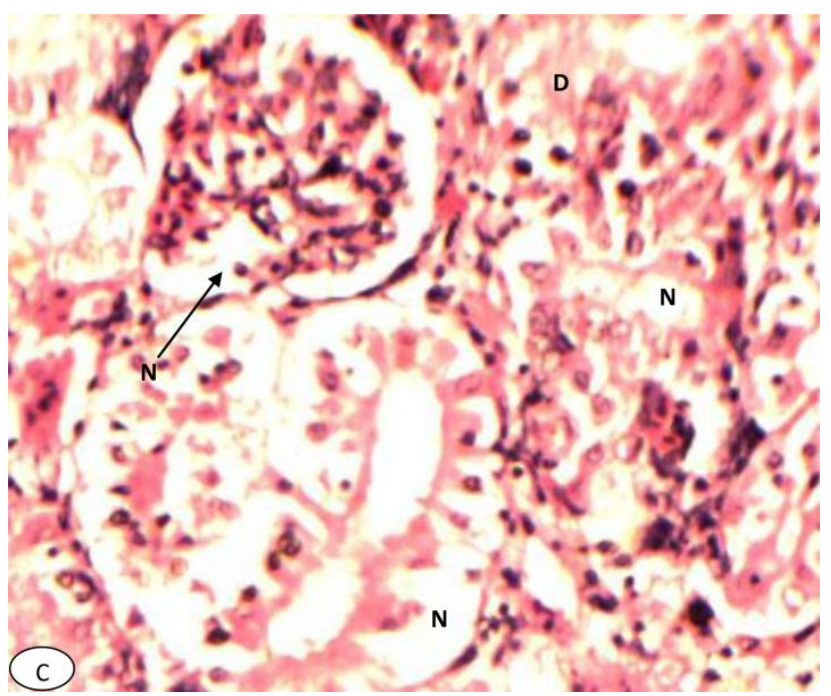

Fig (C) : Kidney section of O. niloticus collected from ElRahawy drain showing : necrosis $(\mathrm{N})$ in renal tubule and glomerulus, degeneration (D) and necrosis (N) in Hematopoietic tissue., HE. X 400

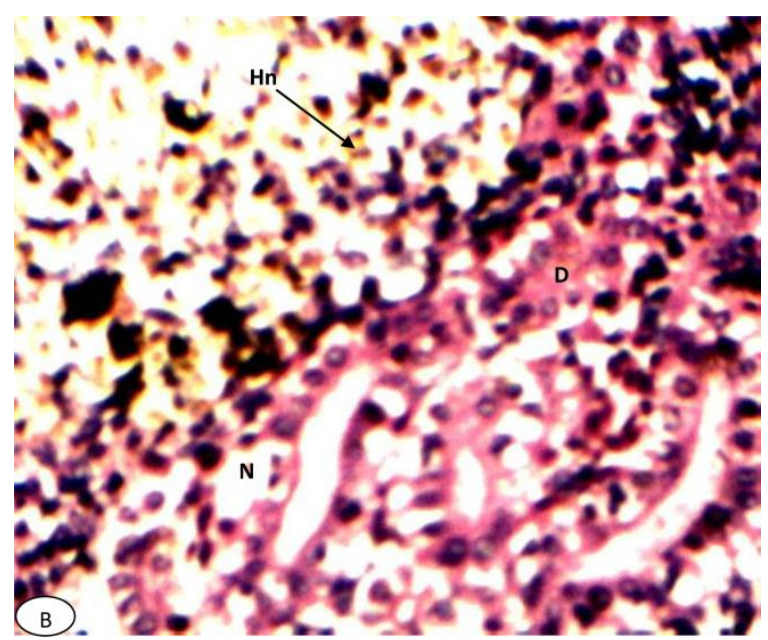

Fig (B): Kidney section of O. niloticus collected from ElRahawy drain showing : degeneration (D), necrosis (N), hemosidrin (Hn) in hematopoietic tissue., HE. X 400

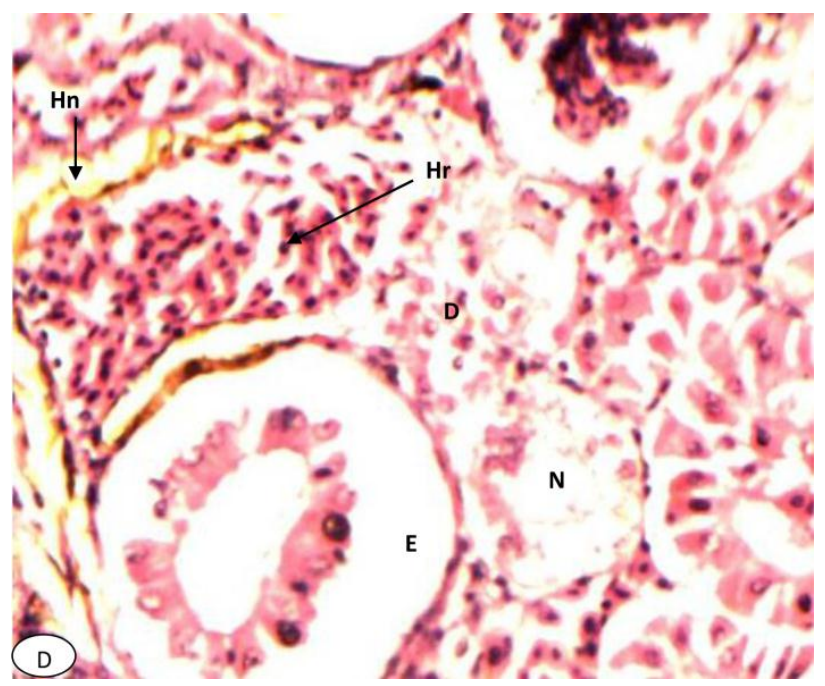

Fig (D): Kidney section of O. niloticus collected from ElRahawy drain showing : hemorrhage (Hr), hemosidrin (Hn) in hematopoietic tissue, edema (E) in renal tubule, necrosis $(\mathrm{N})$ and degeneration (D) in renal tubule and hematopoietic tissue., HE. X 400 


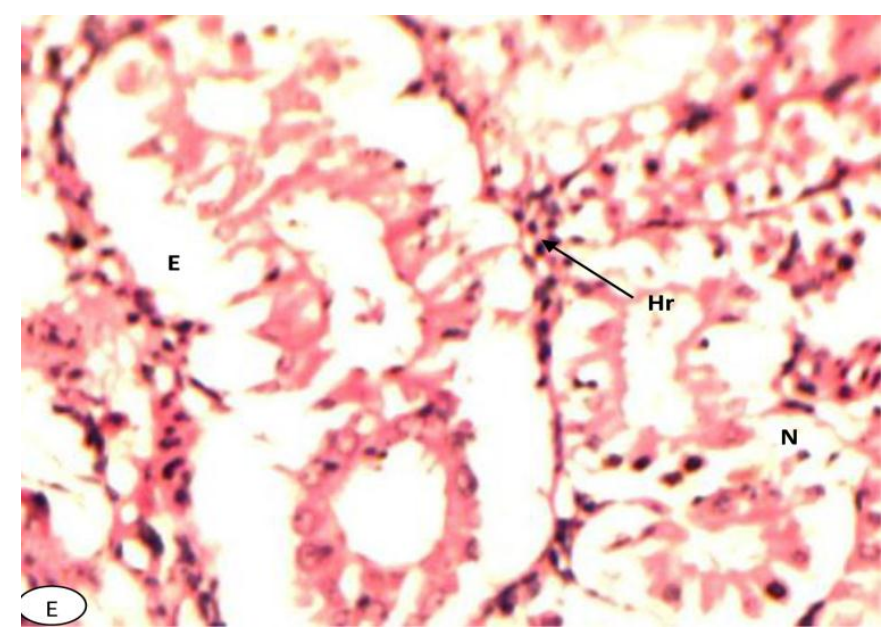

Fig (E) : Kidney section of O. niloticus collected from ElRahawy drain showing : hemorrhage $(\mathrm{Hr})$ in hematopiotic tissue , edema (E), and necrosis $(\mathrm{N})$ in renal tubule ., HE. X 400

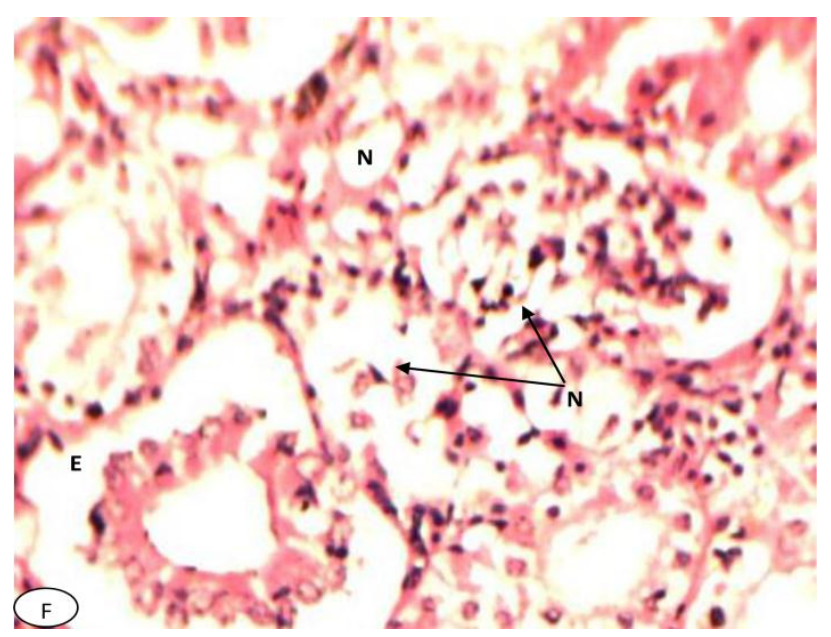

Fig (F) : Kidney section of O. niloticus collected from ElRahawy drain showing : edema (E) in glomerulus, necrosis $(\mathrm{N})$ in renal tubule and glomerulus and hematopoietic tissue., HE. X 400

- Kidney section of O. niloticus

A) - haemorrhage (Hr)

[2] - dageneration (D) ..... in hematopoietic tissue

- necrosis $(\mathrm{N})$..... in renal tubule and glomerulus

B)

$$
\begin{array}{ll}
\text { - degeneration } & \text { (D) } \\
\text { - necrosis } & \text { (N) } \\
\text { - hemosidrin } & \text { (Hn) ..... in hematopoietic tissue }
\end{array}
$$

C)

- necrosis (N) ..... in renal tubule and glomerulus

- degeneration (D)

- $\operatorname{necrosis}(\mathrm{N})$

$$
\text { in hematopoietic tissue }
$$

D) - haemorrhage (Hr)

$[3] \Rightarrow$ - hemosidrin (Hn) .... in hematopoietic tissue

- edema (E) .... in renal tubule

- necrosis (N) in renal tubule and hematopoietic

- degeneration

(D) tissuf

E)

$$
\begin{aligned}
& {[1] \rightarrow \text { - haemorrhage }(\mathrm{Hr}) \ldots . . \text { in hematopoietic tissue }} \\
& \begin{array}{ll}
{[4] \rightarrow-\text { edema }} & \text { (E) } \\
\text { - necrosis } & \text { (N) in refnal tubule }
\end{array}
\end{aligned}
$$

F)

- Oedema in glomerulus 
- Necrosis in renal tubule

in glomerulus

in hematopoietic tissue

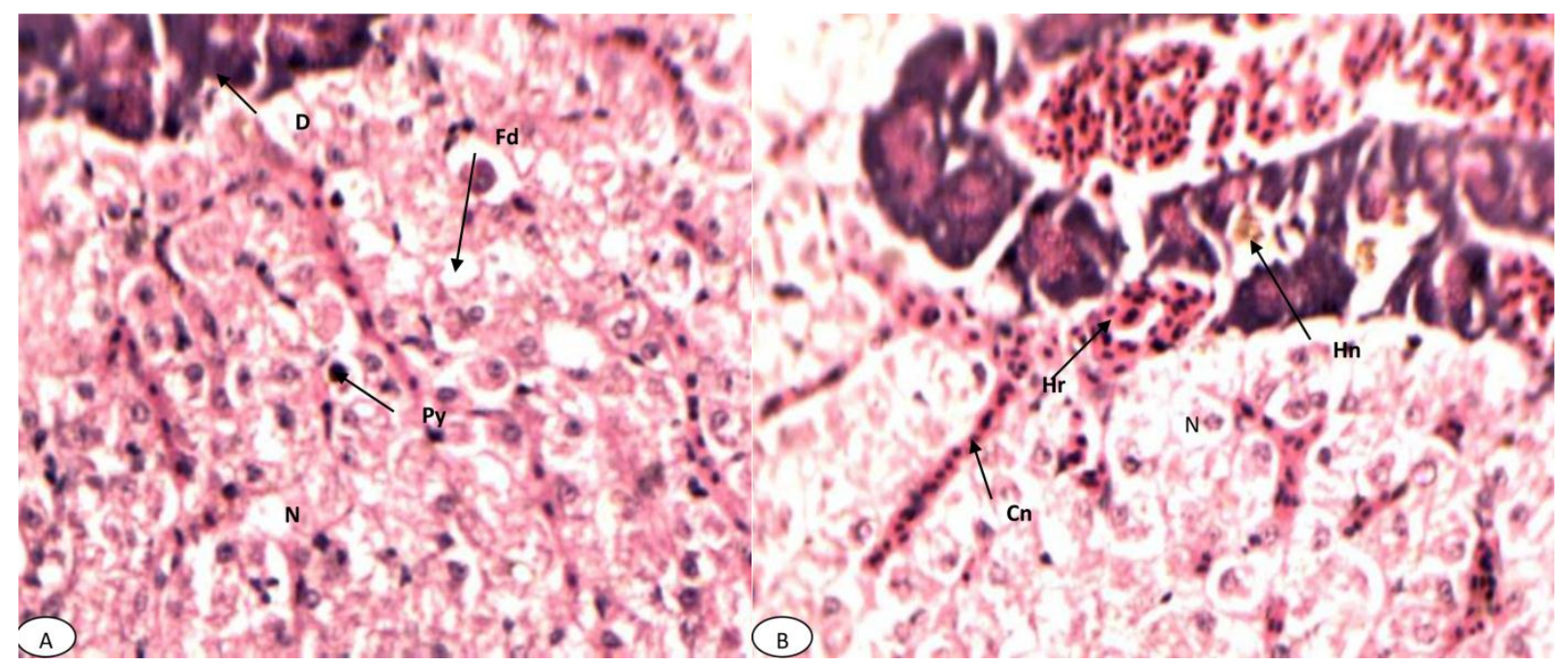

Fig(A) : Liver section of $O$. niloticus collected $F i g(B)$ : Liver section of $O$. niloticus collected from El- Rahawy drain showing : degeneration (D) from El-Rahawy drain showing : hemorrhage (Hr), in blood vessele wall, fatty degeneration $(\mathrm{Fd})$, hemosidrin $(\mathrm{Hn})$ in blood vessele, congestion $(\mathrm{Cn})$ pycnotic (Py) and necrosis (N) in hepatocytes., HE. in blood sinusoids , and necrosis (N) in $\mathrm{X} 400$ hepatocytes., HE. X 400 


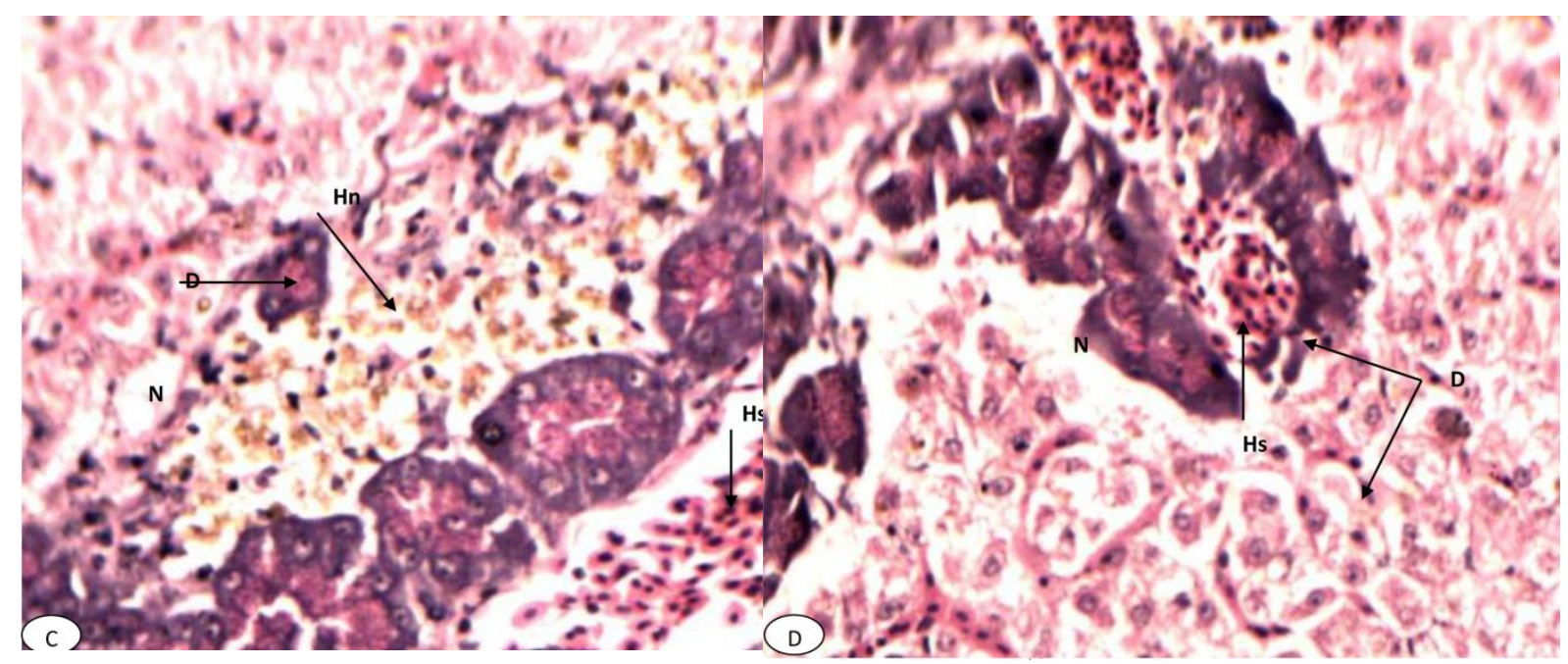

Fig (C) : Liver section of $O$. niloticus collected $\operatorname{Fig}(\mathrm{D})$ : Liver section of $\mathrm{O}$. niloticus collected from El-Rahawy drain showing : hemolysis (Hs), from El-Rahawy drain showing : hymolysis (Hs), hemosidrin $(\mathrm{Hn})$, degeneration in blood vessele necrosis $(\mathrm{N})$ and degeneration (D) in blood vessele wall, and necrosis (N) in hepatocytes., HE . X 400 wall and hepatocytes., HE . X 400 .

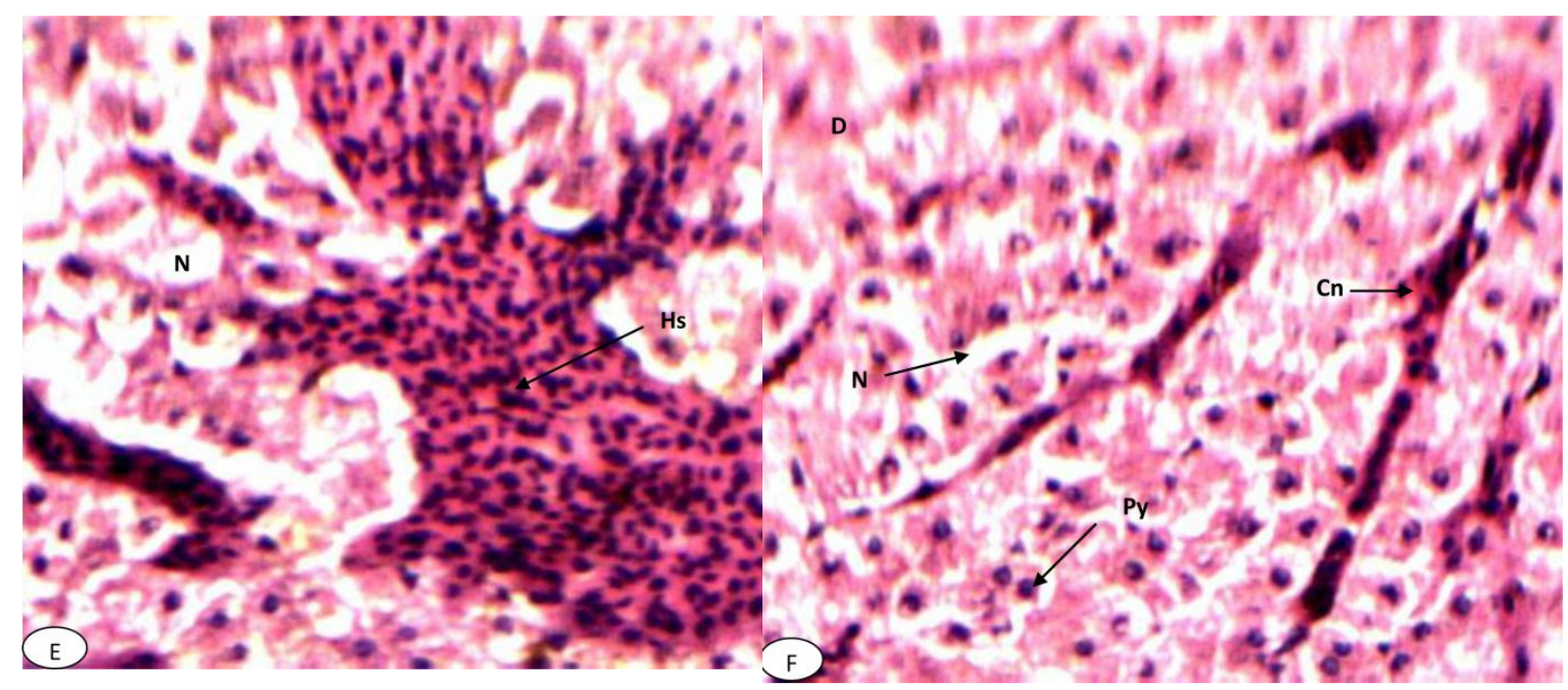

Fig (E) : Liver section of O. niloticus collected Fig (F) : Liver section of O. niloticus collected from El-Rahawy drain showing : hemolysis (Hs), from El-Rahawy drain showing : congestion (Cn) and necrosis $(\mathrm{N})$ in hepatocytes., HE. X 400 in blood sinusoid, pycnotic (Py), necrosis $(\mathrm{N})$, degeneration (D) in hepatocytes., HE . X 400

- $\quad$ Liver section of $O$. niloticus

A. $\quad 3$ - degeneration $(D)$ in blood vessele wall - fatty degeneration (FD)

6 - pycnotic (Py) and -necrosis $(\mathrm{N})$ in hepatocytes

B. - haemorrhage (Hr)

$2 \rightarrow$ - hemosidrin $(\mathrm{Hn})$ in blood vessele

$\vec{r} \rightarrow$ - congestion ( $\mathrm{cn}$ ) in blood sinusoids

and - necrosis $(\mathrm{N})$ in hepatocytes

C. - hemolysis (Hs) 
- hemosidrin (Hn)

- degeneration in blood vessele wall

and - necrosis $(\mathrm{N})$ in hepatocytes

D. - hemolysis (Hs)

- necrosis $(\mathrm{N})$

and - degeneration (D) in blood vessele wall and hepatocytes

E. $\quad \longrightarrow$-hemolysis (Hs)

and-necrosis (N) in hepatocytes

F. - congestion ( $\mathrm{cn})$

- pycnotic (Py)

necrosis (N) and - degeneration (D) in hepatocytes

\section{REFERENCES}

Abdel-Baky. T.E. (2001). Heavy metals concentrations in the catfish Clarias gariepinus ( Burchell . 1882) from River Nile El-Salam Canal and lake Manzala and their impacts conisel and thyroid hormones . Egypt . J. Aquat . Biol . \& Fish. 5(1):79-98.

Abeyede , E. I. (1993). Trace heavy metals distribution in Illisha africana fish organs and tissue . II : chromium, zinc , copper , iron and cobalt . Pak. J. Sci. Res., 36: 333-337 .

Adeogun, A.O. (2012). Impact of Industrial Effluent on Water Quality and Gill Pathology of Clarias gariepinus from Alaro Stream, Ibadan, Southwest, Nigeria, European Journal of Scientific Research, 76(1) : $83-94$

APHA (1998) American Public Health Association. Standard methods for the examination of water and wastewater. APHA, WEF and AWWA, 20 th ed., Washington DC, USA, pp: 1193

Authman, M. M. N. , H . H. Abbas and W.T. Abbas (2013). Assessment of metal status in drainage canal water and their bioaccumulation in Oreochromis niloticus fish in relation to human health . Environmental Monitoring and Assessment, 185 (1): 891-907.

Bahnasawy, M.H. (2001). Levels of heavy metals in catfish, Clarias Gariepinus from different habitats and their effects on some Biochemical parameters. Egypt. , J. Aquat. Biol. \&Fish. , 5(1):99-125.

Barak. N. A. and Mason. C.F. (1990) : Mercury, cadmium and lead in eels and roach. The effects of size, season and locality on metal concentration in flesh and liver. Sci. Tot. Environ. 92:249256.

Bernet, D.; Schmidt, H.; Meier, W.; Brkhardt-Holm, P. and Wahli, T. (1999) Histopathology in fish: Proposal for a protocol to assess aquatic pollution. Journal of Fish Diseases, 22: 25-34.

Egyptian Governmental Law No, 48 (1982), The Implementer Regulations for law 48/ 1982 regarding the proection of the River Nile and water ways from pollution Map. Periodical Bull., 3-4 : 12-35

El Bouraie, M.M., A.A. El Barbary and M, Yehia (2011), Determination of Organochlorine Pesticide (OCPs) in Shallow Observation Wells from El-Rahawy Contaminated Araa, Egypt, Environmental, Engineering and Management, 3(57) : 28-38.

El Bouraie, M.M., A.A. El Barbary, M.M. Yehin and E.A. Motawea, 2010. Heavy metal concentrations in surface river water and bed sediments at Nile Delta in Egypt. Suoseura Finnish Pealand Society, 61 (1): 1-12.

El Bouraie, M.M., A.A. El Barbary, M.M. Yehin and E.A. Motawea ( 2010). Heavy metal concentrations in surface river water and bed sediments at Nile Delta in Egypt. Suoseura Finnish Pealand Society, 61 (1) : 1-12. 
El-Moselhy, Kh. M. (1999). Levels of some metals in fish, Tilapia Caught from certain Egyptian lakes and River Nile, Egypt. J. Aquat. Biol. \& Fish. 3(1):73-83.

El-Sheikh, M.A.. H.I. Salah, D.E. El-Quosy and A.A Mahmoud, 2010. Improving water quality in polluted drauns with free water surface constructed Wetlands. Ecological Engineering, 36: $1478-1484$.

Fent, K. ( 2004). Ecotoxicological effects at contaminated sites. Toxicology, 205(3): 223-240

Gaber, H.S., El-Kasheif, M.A., Ibrahim, S.A. and Authman, M.N.(2013). Effect of water pollution in El-Rahawy Drainage Canal on hematology and Organs of freshwater fish clanas gariepinus world Applied Sciences Journal 21(3) : 329-341

Ghazaly. K . S . : El-Mofty. M. M. and Attia. S. I. (1992). Effects of Locality and tissue type . on heavy metals levels of some commercial fishes from Alexandria. Egypt. Bull. Inst. Oceanogr. \& Fish. . ARE. 18:43-52 .

Goldberg, E.D. (1963) Geochronology with lead-210. In: Symposium on radioactive dating, Athens, November, 1962. Vienna, International Atomic Energy Agency. p. 121-131.

Gomaa .M.; Abou-Arab. A.; Badawy . A. and Naguib, K. (1995) . Distribution pattern of some heavy metals in Egyptian fish organs. Food Chemistry . 53; 385-389.

Khallaf , E.A. , M. Galal and M. Authman (2010). Food and feeding ecology of Oreochromis niloticus ( L, 1757 ) in a Nilotic drainage Canal. In the Proceedings of the First International Conference on Biodiversity of the Aquatic Environment, 13-15 December 2010 , INOCTischreen University, Lattakia, Syria, pp : 225-247.

Khallaf , E.A., Galal . M. and Authman. M. (1998). Assessment of heavy metals pollution and their effects on Oreochromis niloticus in aquatic drainage canals. J. Egypt . Ger. Soc . Zool., 26(B); 39-74.

Lasheen, M.R., F,Kh, Abdel- Gawad, A,A, Alaneny and H.M.H. Abd El bary (2012). Fish as Bio Indicatiors in Aquatic Environmental pollution Assessment: A Case Study in Abu-Rawash Area, Egypt, World Applied Sciences Journal, 19(2) : 265-275.

Linde -Arias, A.R., A.F. Inacio, L.A. Novo, C. de Alburquerque and J.C. Moreira, 2008. Multibiomarker approach in fish to assess the impact of pollution in a large Brazilian river, Paraiba do Sul, Environmental pollution, 156: 974-979.

Marks. P. J. : Plaskett, D. : Potter . I. C. and Bradly . J. S. (1980). relationship between concentration of heavy metals in muscle tissue and body weight of fish from the Swan-Avon estuary .Western Australia. Aust. J. Mar. Fresh water Res..31:783-793.

Mears. H. and Eister. R. (1977). Trace metals in liver from blue fish tautog and tile fish in relation to body length. Chesapeak Science. 18:315-318.

Midhat A. El-Kasheif, Hanan S. Gaber, Mohammed M.N. Authman and Seham A. Ibrahim (2013) . Histopathological and physiological Observations of the Kidney and Spleen of the Nile Catfish Clarias gariepinus inhabiting El-Rahawy drain, Egypt Journal of Applied Sciences Research, 9(1) : 872-884.

Mohamed F.A.S. and Gad, N.sh. (2005). Distribution of some heavy metals in tissues of Oreochromis niloticus, Tilapia Zillii and Clarias lazera (gariepinus) from Abo Zabaal lakes and their impacts on some biochemical parameters and on the histological structures of some organs. Egypt. J. Aquat. Biol. \& Fish .,Vol.9, No.1:41-80 .

Nussey, G.,J.H.J Van Vuren and H.H du Preez (1995). Effect of copper on the haematology and osmoregulation of the Mozambique tilapia, Oreochromis mossambicus (Cichlidae). Comparative Biochemistry and physiology C,111(3): 369-380

Rajeshkumar, S. and N, Munuswamy (2011), Impact of metals on histopathology and expression of HSP 70 in different tissues of Milk fish (Chanas chanas) of Kaetuppalli Island, South East Coast, India Chemosphere, 83:415-421

Roberts, R.J. (2012). Fish Pathology. 4 th ed., Blackwell Publishing Ltd., A John Wiley \& Sons, Ltd., Publloation, The Atrlum, Southern, Chichester, West Sussex, PO19 8SQ, UK, pp:462.

SPSS (2009). SAS Institute Inc., Cary, NC, USA. NOTE: SAS Proprietary Software Version 9.00 (TS $\mathrm{M} 0)$ 


\section{El-Hais et al.}

Skidmore,J. (1964). Toxicity of zine compounds to aquatic animals. with special references to fish. Quart Rev . Biol ..39(3);227-248.

Shenouda. T.S.; Abo-zaid.F.A.; Al-Assiuty, A.l. and Abada. A.E. (1992). Water pollution and bioaccumulation of the highly pollutant agents in different organs of Oreochromis niloticus. near Kafr El-Zayat. Proc. Zool. Soc. A.R.E ..23 (2); 12-25.

Tariq , J.; Ashraf, M. and Jaffar , M. (1993). Metal pollution status of the River Chennab , Pakistan through fish, water and sediment analysis . Toxicol . Environ . Chem ., 38 (3/4); 175-181.

Van der Oost, R.,J. Beyer and N.P. Vermeulen (2003). Fish bioaccumulation and biomarkers in environmental risk assessment a review. Environmental Toxicology and Pharmacology. 13: 57149.

تأثير تراكم المعادن الثقيلة على كلى وكبد أسماك البلطي التيلي القاطنة بمصرف الرهاوي

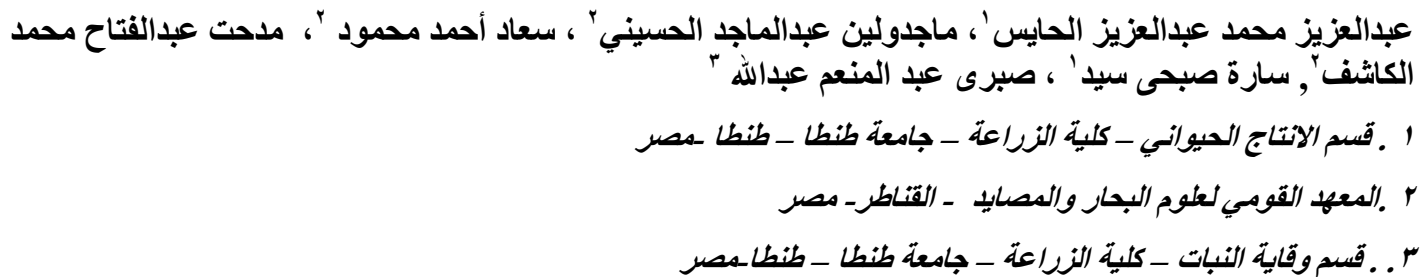

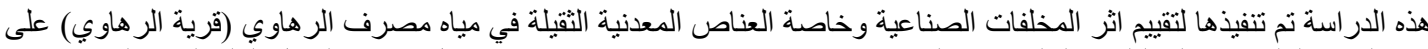

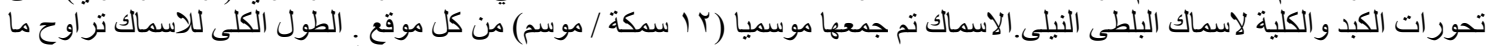

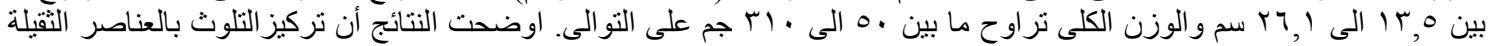

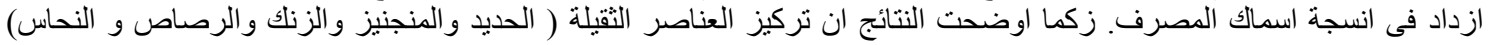

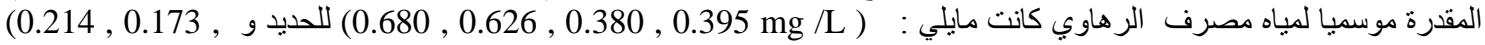
(ل) 0.112 للمنجنيز و ( 0.214 mg /L)

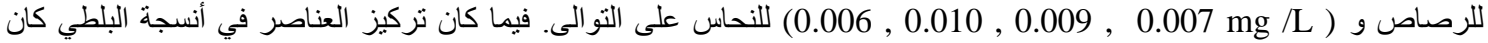

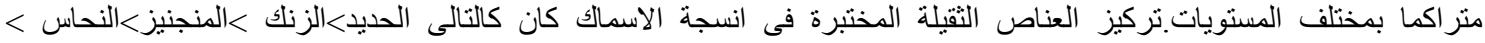

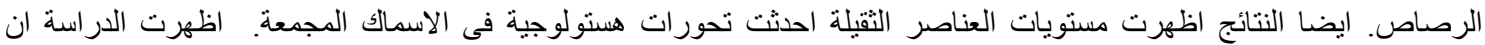

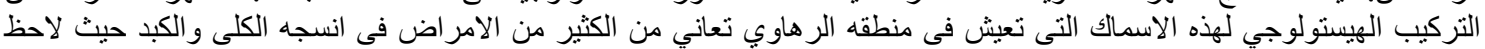

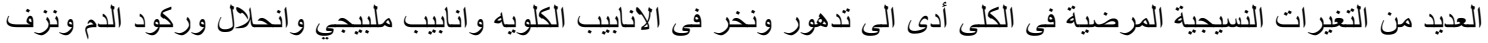

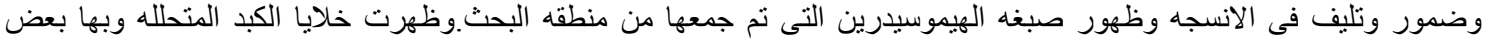

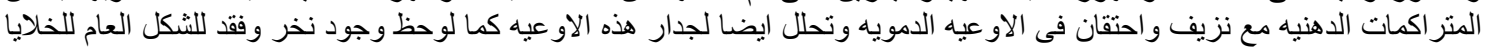

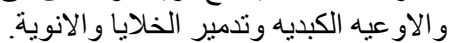

لذا يمكن استخلاص ان المخلفات الزراعية والصناعية احدثت تحورات هستولوجية و مرضية فى كبد وكلية اسماك البلطى النيلى

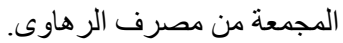

